\begin{tabular}{c} 
International Journal of Engineering \& Technology, $7(3.21)(2018) 120-124$ \\
International Journal of Engineering \& Technology \\
WPC \\
Nebsite: $\frac{w w w . s c i e n c e p u b c o . c o m / i n d e x . p h p / I J E T}{\text { Research paper }}$ \\
\hline
\end{tabular}

\title{
Causes and Solutions of "Tragedy of the Commons" in Natural Resources Management of Muncar Coastal Areas
}

\author{
Dwi Wulandari $^{1}$ *, Emma Yunika Puspasari ${ }^{2}$, Nur Anita Yunikawati ${ }^{3}$, Thomas Soseco ${ }^{4}$, \\ Bagus Shandy Narmaditya ${ }^{5}$, Ni’matul Istiqomah ${ }^{6}$, Prih Hardinto ${ }^{7}$, Sugeng Hadi Utomo ${ }^{8}$, Mit Witjaksono9 \\ ${ }_{1,2,3,4,5,6,7,8,9}$ Faculty of Economics, Universitas Negeri Malang \\ *Corresponding author E-mail: dwi.wulandari.fe@um.ac.id
}

\begin{abstract}
The tragedy of commons exists where natural common resources are overused. Every user is encouraged to maximize their utilization by taking as much as they can, left environment's ability to regenerates behind. As a result, there will be a decreasing result. The condition exists in Muncar in Banyuwangi, Indonesia. This coastal area has to accommodate an increasing number of fishing fleets with more advanced technology, which creates a diminishing volume in fishing catches. This research explores the tragedy of commons in Muncar, Indonesia. We use the qualitative approach with the phenomenological interpretative paradigm. We interviewed stakeholders as well as fishermen in Muncar. The result of this study (1). The increasing number of fishing fleets are accompanied with more advanced technology. This allows fishermen to catch fish in higher volume. Also, there is a negligence in environment-friendly concern because of economic reason. (2). The tragedy of commons is caused by unclear regulation about fish regulation along the Muncar Coastal Area. The development of infrastructure in Muncar is not well equipped with adequate utilities such as disposal waste facilities. Also, the development of industrial zones in Muncar is not well planned.
\end{abstract}

Keywords: tragedy of commons; coastal area; phenomenological approach; fish catching; natural resource management

\section{Introduction}

Basically, marine resources are common resources that anyone can assess openly. Because of limited or lack of obligation to regenerate the resources, every fisherman feels free to catch fish as much as they can. (1) stated that if this condition still exists without an effective social control, then it will cause ruin for everyone. Finally, there is a huge loss for all. This phenomenon is introduced as the tragedy of commons. The tragedy of commons involves overexploitation and imposing mutual externalities upon each other (2). The implication of the tragedy of commons is not only experienced by present generation but also by future generations, indicated by less resources available to be harvested.

The tragedy of commons usually indicated by the increase ability for users to take benefit from the resource. In coastal regions, this can be indicated by increasing number of fishing fleet, equipped with more advanced fishing and storaging technology that allow fishermen to catch more fish and in wider coverage. This condition also worsened by an increase capacity in processing industry. Usually, this increasing capacity is not accompanied with more environment-friendly technology.

The tragedy of commons brings numerous consequences. First of all, there will be a decreasing results. Next, it brings higher competition to access resources, that may results in social conflicts. Lastly, the tragedy of commons that exists today will cause no more resources left for future generations. The glory of fishery of one area will be only recorded in history, not inherited for future generations.
Thus, it is important to identify whether the tragedy of commons is exist in one specific area and find suitable actions to prevent this condition. We go to Muncar to explore this phenomenon. Muncar is main fish catching area in Banyuwangi, Indonesia. Historically, we can trace back Muncar's main role to 1901, when Madura community arrived in Muncar. Their fishing skills the spread out to local people in that area and then inherited for generations. Muncar is the second largest fish auction place in Indonesia, after Bagan Siapi-api in Riau.

Our preliminary results found that there is a decreasing number of fish production in Muncar, from 22.049,29 tons in 2010 to $11.792,98$ tons in 2014. Our conjecture is those decline strongly related to overfishing in Muncar Coastal Area. We investigate this phenomenon to reveals causes and implications of the tragedy of commons in Munar Coastal Area. Then, we propose some actions to overcome this problem.

\section{Literature Review}

\subsection{Economic Theories of the Fishery}

Gordon, (3) indicated fish that are included in his analysis as demersal fish. Demersal, or bottom-dwelling fishes, such as cod, haddock, and similar species and the various flat-fishes, are relatively non-migratory in character. They live and feed on shallow continental shelves where the continual mixing of cold water maintains the availability of those nutrient salts which form the fundamental basis of marine-food chains. The fish is uniquely located in one area, separated by natural barriers which prohibited 
their movement. Thus, every fishing ground probably have their own unique fish morphology.

The optimum degree of optimization is defined as any treatment that maximize the net economic yield. It can be observed through the difference between total cost and total revenue (total value production). It can be expressed in a function of the degree of fishing intensity. (3) expressed the function that accommodates relationship between fishing effort and total value produced as in figure 1 .

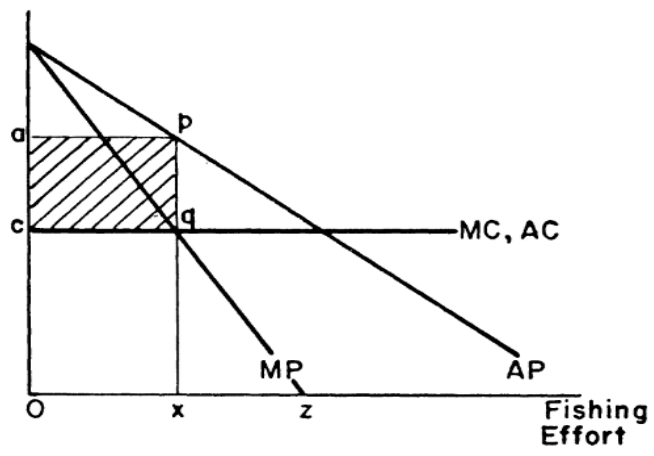

Fig. 1: The Optimum Intensity of Utilization Source: Gordon (1954)

In figure 1 the optimum intensity of utilization of a particular fishing ground is shown. The curve $A P$ and $M P$ represent, respectively, the average productivity and marginal productivity of fishing effort. While marginal cost and average cost are constant and identical, shown by $M C$ and $A C$. The $O x$ is the optimum intensity of effort on this fishing ground. It provides the maximum net economic yield indicated by the shaded area apqc. The area apqc is regarded as the rent yielded by the fishery resource. Under the given condition, $O x$ is the best rate of exploitation for the fishing ground.

The analysis is then expanded to more than one fishing ground, as sea fishery is not private property. Each fisherman has no legal ownership for one specific sea bottom. Thus, everyone has choice to move to another fishing ground.

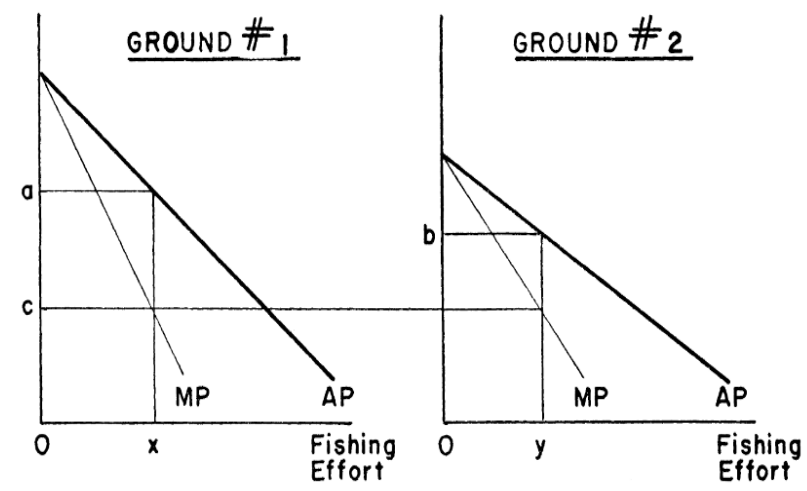

Fig. 2: The Optimum Intensity of Utilization in Two Fishing Grounds Source: Gordon (1954)

In figure 2, two fishing grounds of different fertility (or location) are shown. Fishing ground 2 will yield smaller amount of total product and average product than fishing ground 1 . Thus, there is difference in maximum total net yield, which is $O x$ in fishing ground 1 and $O y$ in fishing ground 2. A fisherman who starting to switch from fishing ground 1 to 2 realized that he does not care about marginal productivity but for average productivity. They later realized that the greater total yield may obtained. If fishing effort were allocated in the optimum fashion, as shown in figure 2, with $O x$ on 1, and $O y$ on 2, this would be a disequilibrium situation. Each fisherman could expect to get an average catch of $\mathrm{Oa}$ on 1 but only $O b$ in 2 . Therefore, fishermen would shift from 2 to 1 .

\subsection{Tragedy of Commons}

Hardin, (1) stated that tragedy of commons is a condition that leads to individuals' unhappiness because of common goods. This theory is rose from classical thought that government do not regulate common goods. (1) gave example herdsman who seeks to maximize his gain. Then, he faces positive and negative component of adding one more animal to his herd. The positive component is a function of the increment of one animal. Since the herdsman receives all the proceeds from the sale of the additional animal, the positive utility is nearly +1 . On the other hand, the negative component is a function of the additional overgrazing created by one more animal. Since, however, the effects of overgrazing are shared by all the herdsmen, the negative utility for any particular decision-making herdsman is only a fraction of -1 .

Adding together the component partial utilities, the rational herdsman concludes that the only sensible course for him to pursue is to add another animal to his herd. But this is the conclusion reached by each and every rational herdsman sharing a commons. Therein is the tragedy. Each man is locked into a system that compels him to increase his herd without limit-in a world that is limited. Ruin is the destination toward which all men rush, each pursuing his own best interest in a society that believes in the freedom of the commons. Freedom in a commons brings ruin to all of the tragedy of commons as sheep.

The main cause of tragedy of commons is the open access to resources for instance fresh air, water, fish, and forest, which leads to overexploitation (3); (1). Solutions offered to overcome tragedy of commons are:

1. Ownership transfer from common to private or government owned. (1); (4)

2. Communication (5)

3. Monitoring and sanctioning (6)

4. Output sharing within subgroup $(7,8)$

5. Establishing rules through voting binding (9)

6. Punishment (10)

7. Develop cultural institution in fishermen communities to protect open access resources (11)

8. Innovation from social institutional attribute (the people, or ganizations, and system of values and incentives and the ways behavior) that collectively and individually affect fishing communities (12)

9. Implement marine cadastre (12)

\section{Methodology/Materials}

This research used a qualitative phenomenological approach with an interpretative paradigm. This approach is including in interpretative paradigm itself. Methods used in the interpretative paradigm includes analyzing social activity through detailed observation of individuals in natural circumstances which aimed to reach better understanding and interpretation of how people create and maintain their social world. The main assumption of the paradigm is every individual actively interpret their experience by giving sense for each activity. The paradigm also believes that knowledge is obtained from conscious experience. This is why phenomenological researchers should not justify whether one statement provided by informants. It is an obligation for researchers to investigate how the information can be obtained by informants or how the express the statement.

We collect data through (1) in-depth interview, (2) observation, and (3) study of documents. We asked fishermen community in Muncar Coastal Area. All of them are fishermen, fishing fleet's owners, and ship crew. We also ask local government, as well as local industries. Our observation is aimed to capture offshore activities, catchment handling in land, and fish processing activity. 
Lastly, we also investigate relevant literature to support our findings.

\section{Results and Findings}

\subsection{Economic Activity in Muncar}

Muncar is located in eastern tip of Java Island, Indonesia. District (kecamatan) of Muncar located in Regency (kabupaten) of Banyuwangi, Province (provinsi) of Jawa Timur, Indonesia. Muncar have total area 5.782,50 square kilometer with 291,5 kilometer of coastline. In 2013, (13) recorded that Muncar (130.270 in population) was the most populated district in regency of Banyuwangi. There are ten villages in Muncar: Blambangan, Kedungrejo, Kedungringin, Tembokrejo, Sumberberas, Wringin Putih, Kumendung, Tapanrejo, Sumbersewu, and Tambakrejo. The most populated village is Kedungrejo (14.269 in population) and the least populated one is Kumendung (4.901 in population).

Muncar is the main fish catching area in Regency of Banyuwangi. It produce approximately 95 percent of fish catchment in Banyuwangi. Table 1. shows fish catchment production in Banyuwangi as shown in table (14)

Table 1: Fish Catchment in Banyuwangi, 2009-2010

\begin{tabular}{|l|l|r|r|r|r|}
\hline \multirow{2}{*}{ No. } & District & $\begin{array}{c}\text { Production } \\
\text { (tonnes) }\end{array}$ & $\begin{array}{c}\text { Value } \\
\text { (million } \\
\text { rupiah) }\end{array}$ & $\begin{array}{c}\text { Production } \\
\text { (tonnes) }\end{array}$ & $\begin{array}{c}\text { Value } \\
\text { (million } \\
\text { rupiah) }\end{array}$ \\
\cline { 3 - 6 } & & 48.304 & 147.948 & 27.746 & 137.604 \\
\hline 1. & Muncar & 1.284 & 5.770 & 411 & 2.831 \\
\hline 2. & Pesanggaan & 426 & 2.237 & 700 & 3.833 \\
\hline 3. & Purwoharjo & 672 & 4.370 & 160 & 1.265 \\
\hline 4. & Wongsorejo & 532 & 3.034 & 66 & 468 \\
\hline 5. & Kalipuro & 8,54 & 55 & 27 & 196 \\
\hline 6. & Banyuwangi & 4,21 & 25 & 17 & 111 \\
\hline 7. & Kabat & 126 & 808 & 104 & 779 \\
\hline 8. & Rogojampi & 15 & 93 & 29 & 271 \\
\hline 9. & Tegaldlimo & 3,56 & 19 & 0 & 0 \\
\hline 10. & Siliragung & 2,71 & 15 & 0 & 0 \\
\hline 11. & Bangorejo & 51.371 & 161.438 & 29.264 & 147.362 \\
\hline & Total & & & & $\mathbf{2 0 1 0}$ \\
\hline
\end{tabular}

From table 4.1, Muncar is the biggest fish catchment contributor in Banyuwangi. In period of 2009-2010, it produced approximately $94 \%$ of total fish catchment in Banyuwangi. The number of catching fish ships or boats in Muncar is described in table 4.2 by (14).

Table 2: Catching Fish Ships in Muncar, 2000-2010

\begin{tabular}{|c|r|r|r|r|r|r|}
\hline \multirow{2}{*}{ Description } & \multicolumn{5}{|c|}{ Year } \\
\cline { 2 - 7 } & $\mathbf{2 0 0 0}$ & $\mathbf{2 0 0 2}$ & $\mathbf{2 0 0 4}$ & $\mathbf{2 0 0 6}$ & $\mathbf{2 0 0 8}$ & $\mathbf{2 0 1 0}$ \\
\hline a. Ship & & & & & & \\
\hline $\begin{array}{l}\text { Ton Gross } \\
\text { 5-10 Gross } \\
\text { Ton }\end{array}$ & 267 & 533 & 566 & 566 & 566 & 566 \\
\hline $\begin{array}{l}\text { 10-30 Gross } \\
\text { Ton }\end{array}$ & 786 & 198 & 193 & 189 & 189 & 189 \\
\hline b. Boat & & & & & & \\
\hline $\begin{array}{l}\text { Perahu } \\
\text { Tanpa Mo- } \\
\text { tor (Boat } \\
\text { without mo- } \\
\text { tor engine) }\end{array}$ & & 258 & 215 & 121 & 96 & 121 \\
\hline $\begin{array}{l}\text { Perahu Mo- } \\
\text { tor Tempel } \\
\text { (Boat with } \\
\text { motor en- } \\
\text { gine) }\end{array}$ & 1.284 & 1.112 & 1.070 & 1.074 & 1.401 & 1.074 \\
\hline Total & & & & & & \\
\hline
\end{tabular}

From table 2, in Muncar, the population of boats (with motor engine) is far above ships. Their affordable price makes more fish- ermen can own it. While ships are commonly owned by juragan (ship's fleets owner).

The main commodities of catching fish in Muncar are lemuru (Sardinella lemuru), tuna (Thunnini), and flying fish (Decapterus macrosoma). All fishing catchment then brought to Tempat Pelelangan Ikan (TPI/Fish Auction Centre) in Muncar. Approximately 500 tonnes catching fish are traded every day, which 90 percent of them are sent to local industries in Muncar. Fish processing industries in Muncar include cold storage, canned fish, pemindangan (fish preservation using salty boiled water), pengasinan (salting), flour fish, fish oil, and fish feed.

\subsection{Social Aspect in Muncar}

Madura community is the largest ethnic group in Muncar. This condition bring hardworking culture among population in Muncar. Social stratification that exist in fishery sector in Muncar are grouped into two major groups based on their position: ocean and land. In ocean community, there are social stratification based on income received or assets owned. The lowest group is nelayan pandega (ship crew). They do not own ship nor other catching equipment they rely on their physic to work in other fishermen's ship. Secondly, nelayan penggarap (fishermen), who also own their ships or catching equipment. They, with help from whip crews, use their own ships to catch fish. Lastly, the highest class in society in Muncar is nelayan pemilik/ juragan/ juragan darat (ship fleet's owner). Usually they have more than five big ships and more smaller ships. They practically do not sail, but trust their ships to juragan laut or captain.

The next major group is land-based community. The first is owner of industries (cold storage, canned sardines, pindang (salty boiled water-preserved-fish, and fish flour. For industries owners, when there is limited fish supply from Muncar's fishermen, they will easily search alternative supply from other regions or even from other countries to fulfill their production capacity. Then, there are enterpreneurs, who include food stalls owners, fresh fish or fishbased-products traders, fishing catchment tools traders, and other fishery-related-products traders). The last social group is workers, who work in the industries.

In Muncar, juragan (ship fleet's owner) positioned in the highest social class. This is caused by their abundance capital. It makes them strong enough to anticipate fluctuated fish catchment. Their ships are equipped with modern fishing tools (commonly purse seine) with larger cooling container which can sail in further distance. Juragan also have sufficient capital for sailing cost (approximately seven million rupiah for 20 days to buy fuel and cooling equipment). The same condition exist for nelayan penggarap (fishermen), even though they have fewer and smaller ships and lower financial capacity.

The most vulnerable condition exist in lowest class: nelayan pandega (ship crew). Their income will depend on ship owner's decision whether to start catching fish or no. If their "boss" decide to send the ship to ocean, the crew wll be called to join. Again, the nett income will depend on how much fish they can catch. In contrary, if the "boss" decided not to send the ship, the crew will find alternative jobs to fulfill their daily needs (usually they shift to be ojek (motorcycle public transportation driver or construction workers).

The way of living (that includes fishing technique) among fisheryrelated population in Muncar is full of tradition, which is inherited from their ancestors. They still practice traditional celebrations and obey certain period in catching or not to catching fish. There is a upacara petik laut, a ceremony which usually held in lunar day in Muharram month (Islamic calendar) or Syuro month (Javanese month) to give thanks to God for previous years and also ask God's gift in future years in term of easines to catch fish and protection from disasters or accidents. The ceremony is full of Madurese ethnic accesories, for instance Sakera clothes, black trousers, and celurit (traditional knife of Madura). 
Other tradition that still implemented among fishermen in Muncar is select hari baik (good day) to start catching fish. They believe, if they go fishing in hari baik, they will get satisfied results. In contrary, if they ignore hari baik, they will get unsatisfied results or even accident or disaster. The other tradition is their obedience to four basic pilars: buppa' (father), babbu (mother), guru (teacher), and rato (leader or government). Muncar's fishermen (which mostly of them are Madurese) are hardworkers, that can be seen from their slogan abantal ombak asepo angen (make wave as our pillow and wind as our blanket). This philosophy reflects their strong passion to catching fish on the sea. When they arrive in the ocean, it will shame for them to go back to their house without bring satisfied catchment results.

\subsection{Overfishing in Muncar}

In period of 2010 to 2014, there was decreasing results of fish catchment in Muncar. Table 3 shows production of catchment fish in Muncar, 2010-2014 by (13)

Table 3: Fish Catchment Production in Muncar, 2010-2014

\begin{tabular}{|l|l|l|}
\hline No & Year & Production (tonnes) \\
\hline 1. & 2010 & $22.042,29$ \\
\hline 2. & 2011 & $16.526,72$ \\
\hline 3. & 2012 & $11.459,01$ \\
\hline 4. & 2013 & $8.010,77$ \\
\hline 5. & 2014 & $11.792,98$ \\
\hline
\end{tabular}

From table 3, there was a decreasing number of production of fish catchment in Muncar. In 2010, there was 22.042 tonnes of fish production. In 2013, the figure is drastically decreased to $8.010,77$ tonnes. This figure rose to $11.792,98$ tonnes in 2014. This decreasing production is recently discussed by (15-18). They found that since its introduction in 1972, pukat cincin (purse seine), successfully replace other catching tools among Muncar's fishermen. This resulted an increasing number of fishing fleets in Muncar, which then followed by an increase in fish catching. In their studies, they found that there is overcapacity in fish catching. Eventhough they found that lemuru fish is overexploited, they realized that catching fish in Muncar is still run smoothly, without any intention to reduce the excessive catchment volume.

Related to this findings, we refer to (19) who stated in the relationship with fishery sector, fishermen play four roles: First, continuously exploit resources without any concern to the limitations. Second, exploit resources and at the same time ruin the environment. The examples are people cut mangrove and collect seasand and coral reefs. Third, exploit resources using destructive ways, for instance using fish bomb and potassium cyanide or using environment unfriendly nets like trawl or minitrawl. Fourth, exploit resources and at the same time try to conserve the environment. Fishermen in Muncar conduct the three first roles. This is an implication of tenurial area status in Muncar, where everybody have access to resources. The fourth role is minority conduct in Muncar, especially by custom group or local community.

\subsection{The Tragedy of Commons}

We identified many causes that create tragedy of commons in Muncar. They are: Firstly, scarcity of fish resources. This caused by overfishing (because of increase in ship fleets and using more advanced technology) and environment degradation (because of use of bomb, potassium cyanide, and excessive catchment tools.). Our respondents agreed that more advanced technology allow them to catch more fish. This creates higher savings accumulation among ship fishing fleets. Thus, more ships are ready to catching fish in the same fishing grounds. As a results, ship owner are strongly encouraged to push their fleets to search fish in longer distance.

Secondly, exploitation of resources which doesn't followed by environment and sustainability awareness. Higher volume of fish- ing catching in Muncar creates more processing industries in that area. But, the industries give poor impact on environment, indicated from their poor waste disposal system. They easily dispose their waste to rivers, which all of the are finally ended in the ocean. Waste that are brought by the stream will affect fish nest or coral reefs, and finally reduce fish regeneration. For fishermen, this leads to a decreasing fishing catchment volume.

Thirdly, the gap of fishing catchment tools among groups of fishermen in Muncar. Some fishermen in Muncar use traditional fishing catchment tools, while others use more advanced technology. Lemuru fish, which are abudantly available in Bali Strait, ignite juragan (ship fleets owner) to buy better ship which can catch more ship and in wider catchment area. A new 30 Gross Ton purse seine ship (approximately 20 meters length), which allow them to catch lemuru effectively - up to 50 ton-will costs 3 billion rupiah. This is a relatively high capital that not everyone can afford it. This ship is the most favorable among juragan in Muncar. Thus, every juragan need to expand their business by add more purse seine ships. The additional ship will results an increasing speed of resource draining.

Fourthly, a huge development in coastal villages that drives to higher pressure on population. As population increase, they need more space to build houses, social infrastructure and industries. This development is not followed by build better sanitation or waste management system. Households throw their waste to rivers or ocean, that potentially give negative accumulation in fishing grounds. On the other hand, as families grow, there are higher pressure to feed them. This makes higher social tension in fishing in the same fishing grounds.

Fifthly, there are no synergistic coordination among stakeholders in Muncar. Government seemed give too many attention to economic sector, indicated by its concern on fish and fish-basedproducts production. Government promote Muncar as the biggest fish producer in east java. But on other side, they do not build strict regulations that control maximum allowed catching tools and ship's size, allotment of fishing grounds, and seasonal fishermen from other regions so that overexploitation can be avoided.

\subsection{Solutions}

The spirit of our offered solution is based on Hardin (2009). His idea, which can traced back to 1968 , is to prevent "fouling our own nest" as long as we behave only as independent, rational, and free-enterprisers. Education can counteract the natural tendency to do the wrong thing. But the inexorable succession of generations requires that the basis for this knowledge be constantly refreshed. Far before legislation takes place, human have to put morality in their mind. It should be their interest to leave same units of resources for their descendant. Then, formal legislation will take place to formulate formal rule. It will need less punishment if population give big concern about morality.

Building morality is a big job, since people still focus on prosperity, especially in Muncar, where the huge income disparity is still exists. The focus should be given on social capital development. As Muncar population is dominated by one ethnic group, where the family and neighborhood relationship still strongly exists, it will be more benefit for them to employ the relationship to gain long term purposes. Currently, they use the relationship only for short-term purposes only (for example, to gain soft loan or to ask for new job opportunities), which should be swifted to be arranged to gain long-term purposes (for example to make fish resource continuously available).

It is important to create sinergy between all elements in society and government. Currently, the relationship between highest and lowest class of society in Muncar is blocked by wide income disparity between them. Juragan have big power in decision making especially in fishery sector. Lower class of society will only take part as decision takers. They will not actively join in every proenvironment activity as their focus is to obtain sufficient income to fulfill their daily needs. 
The first action should be taken is to diminish gap between rich and poor. This step can be taken by empower paguyuban (social group) in low class society. In Muncar, currently there is fishermen organization, namely Patembayan Nelayan Pesisir Kedungrejo (social group of fishermen in Kedungrejo), that accommodates 109 people. But they do not have enough power to intervene decision making in fishery sector. The second action is to create collaborative resource management among stakeholders: community (ship fleet's owner, ship crews, industries, and fishbased-products agents) and government. This synergy is called as co-based community management. This type of management can avoid excessive dominant role of one party.

The second action is to develop co-based community management involves community as well as government in resource management, starting from planning, doing, taking benefits, and supervising. Responsibilities and authorities should not be accumulated in one or two parties only, but equally distributed among all stakeholders based on their capacity (in human resource, infrastructure, or legal aspect). This synergy is not merely static legal formal structure but dynamic process that creates new social institutional structure. By doing this synergy, there will be one new social community that have same vision to enhance their living standard and at the same time leaving valuable resources for future generations.

\section{Conclusion}

The tenurial area in Muncar coastal area bring consequences of common property and open access for each fisherman, that creates overfishing. Overfishing is mainly caused by the increase number of modern ships that equipped with modern technology. Overfishing also worsened by destructive catching methods that degrade environment. All of them create tragedy of commons in natural resources in Muncar. The tragedy brings decreasing fish catchment and lowering income received. People now have to sail in longer distance to find fish. This potentially creates higher social conflict among them

Solutions offered are (1) reduce gap between rich and poor. This action can boost low class of society's involvement in every decision making. (2) Implement collaborative resource management by involving all elements in community (fishermen, fish traders, industries) as well as government that may avoid excessive dominant role of specific parties in the exploitation of coastal area in Muncar.

\section{References}

[1] Hardin G. The Tragedy of the Commons*. Journal of Natural Resources Policy Research. 2009;1(3):243-53.

[2] Hsu S-L. What Is a Tragedy of the Commons-Overfishing and the Campaign Spending Problem. Alb L Rev. 2005;69:75.

[3] Gordon HS. The economic theory of a common-property resource: the fishery. Journal of political economy. 1954;62(2):124-42.

[4] Bajema CJ. Garrett James Hardin: Ecologist, educator, ethicist and environmentalist. Population \& Environment. 1991;12(3):193-212.

[5] Van de Kragt AJ, Orbell JM, Dawes RM. The minimal contributing set as a solution to public goods problems. American Political Science Review. 1983;77(1):112-22.

[6] Ostrom E, Walker J, Gardner R. Covenants with and without a sword: Self-governance is possible. American political science Review. 1992;86(2):404-17.

[7] Schott S, Buckley NJ, Mestelman S, Muller RA. Output sharing in partnerships as a common pool resource management instrument. Environmental and Resource Economics. 2007;37(4):697-711.

[8] Heintzelman MD, Salant SW, Schott S. Putting free-riding to work: a partnership solution to the common-property problem. Journal of Environmental Economics and Management. 2009;57(3):309-20.

[9] Walker JM, Gardner R, Herr A, Ostrom E. Collective choice in the commons: Experimental results on proposed allocation rules and votes. The Economic Journal. 2000;110(460):212-34.
[10] Kroll S, Cherry TL, Shogren JF. The impact of endowment heterogeneity and origin on contributions in best-shot public good games. Experimental Economics. 2007;10(4):411-28.

[11] Bender SW. Castles in the Sand: Balancing Public Custom and Private Owndership Interests on Oregon's Beaches. Or L Rev. 1998;77:913.

[12] Amu-Mensah MA, Amu-Mensah FK, Abban EK. Social Institutional Influence on Fisheries in Two Fishing Communities in the Volta Lake in Ghana. Sociology Mind. 2014;4(04):305.

[13] Statistik BP. Laporan Bulanan Data Sosial Ekonomi. Jakarta: Badan Pusat Statistik. 2014.

[14] Witry SDB. Kajian produksi hasil tangkapan didaratkan di Pelabuhan Perikanan Pantai Muncar Kabupaten Banyuwangi sebagai bahan baku industri pengolahan. 2011.

[15] Berkes F. Managing small-scale fisheries: alternative directions and methods: IDRC; 2001.

[16] Merta I, Widana K, Basuki R. Status of the lemuru fishery in Bali Strait: its development and prospects. 2000.

[17] Setyohadi D. Studi potensi dan dinamika stok ikan lemuru (Sardinella lemuru) di Selat Bali serta alternatif penangkapannya. Jurnal Perikanan Universitas Gadjah Mada. 2009;11(1):78-86.

[18] Buchary EA. In search of viable policy options for responsible use of sardine resources in the Bali Strait, Indonesia: University of British Columbia; 2010.

[19] Kusnadi. Nelayan: strategi adaptasi dan jaringan sosial: Humaniora Utama Press; 2000. 